Joanna Mysona Byrska

\title{
PRACA JAKO ŹRÓDŁO SZCZĘŚCIA I RADOŚCI W SPOŁECZEŃSTWIE KONSUMPCYJNYM
}

"Geld macht kein Glück, aber es beruhigt"1

Stare powiedzenie niemieckie

W pracy człowiek spędza codziennie ponad 8 godzin. Jaka praca może dawać człowiekowi poczucie szczęścia? Jakie powinny być spełnione warunki, by człowiek co rano szedł do swojej pracy z radością, z poczuciem misji i sensu swoich wysiłków, które nie ograniczają się do zarabiania na życie? Pytania te skierowane są do człowieka, który jest mieszkańcem bogatego świata konsumpcji, do członka społeczeństwa konsumpcyjnego. W świecie konsumpcji preferowane są wartości materialne, mierzalne i łatwo dostrzegalne gołym okiem. O statusie, sukcesie i, wydaje się, że również szczęściu i radości w tym świecie decyduje przede wszystkim materialny poziom życia i ilość posiadanych dóbr. Jak w świecie konsumpcji wygląda praca, która daje człowiekowi szczęście? Czy jest ono możliwe do osiągnięcia przez każdego konsumenta? A może świat konsumpcji, tak piękny i pociągający na pierwszy rzut oka, jest bezwzględny i okrutny dla człowieka i jedynie wybranych czyni szczęśliwymi? Wydaje się, że świat konsumpcji jest światem dla tych, którzy mają dostatecznie wiele, by móc zapewnić sobie odpowiedni poziom konsumpcji oraz pracy, która tę konsumpcję umożliwia. Na powyższe wątpliwości i pytania stara się udzielić odpowiedzi poniższy tekst.

1 Pieniądze szczęścia nie dają, ale uspokajają. 
We współczesnym społeczeństwie rozpowszechnione jest pragnienie i żądanie szczęścia. Jean Baudrillard w swoich analizach społeczeństwa konsumpcji wprost zaliczył szczęście do nowych praw konsumenta ${ }^{2}$. Każde prawo oznacza dla kogoś zobowiązanie. Społeczeństwo konsumpcyjne nie jest jednak społeczeństwem, które troszczy się specjalnie o swoich członków. Konsumenci, którzy je tworzą, są skupieni na sobie i swojej konsumpcji. Ci, którzy nie mają wystarczających środków, by konsumować na odpowiednim poziomie, mogą spaść w hierarchii społecznej aż na sam dół - a wówczas stają się, jak nazywa ich Zygmunt Bauman, „ludźmi - śmieciami”, „ofiarami towarzyszącymi” lub „ludźmi - odpadami”", których jak śmieci nikt nie potrzebuje i nie chce mieć blisko siebie, a którzy pojawiają się w efekcie rozwoju społeczeństwa konsumpcyjnego, ponieważ nie są w stanie sprostać jego wymaganiom.

Kto zatem powinien poczuć się zobowiązany do zapewniania konsumentowi możliwości realizacji jego praw, w tym prawa do szczęścia, o którym mówi Baudrillard? Społeczeństwo konsumpcyjne jest oparte na porządku demokratycznym, zatem wydaje się, że to odpowiednie demokratyczne gremia powinny o wspomniane powyżej prawa zabiegać. Problem polega jednak na tym, że konsument jest skupiony na sobie i w demokratyczne działania się raczej nie angażuje. O swoje prawa zaczyna zabiegać wówczas, gdy są mu odbierane i nie może dalej spokojnie egzystować i konsumować 4 .

${ }^{2}$ J. Baudrillard, Społeczeństwo konsumpcyjne. Jego mity i struktury, tłum. J. Królak, Warszawa 2006, s. 45-46.

${ }^{3}$ Z. Bauman, Życie na przemiat, tłum. T. Kunz, Kraków 2004, s. 25. Terminy „ofiara towarzysząca”, „straty uboczne” zaczerpnięte zostały przez Baumana z terminologii stosowanej przez wojska ekspedycyjne. O „ludziach - odpadach” zob.: Z. Bauman, Straty uboczne. Nierówności społeczne w epoce globalizacji, tłum. J. Hunia, Kraków 2012, s. 11.

${ }^{4}$ Konsumentów w polskim piśmiennictwie nazwano kilka lat temu lemingami politycznymi. Odnośnie do lemingów zob. M. Janicki, W. Władyka, Kim jest polityczny leming? Strategia leminga, „Polityka”, 10 lipca 2012, http://www.polityka.pl/tygodnikpolityka/ kraj/1528687,1,kim-jest-polityczny-leming.read (8.12.2015). 
Według Hannah Arendt powszechne żądanie szczęścia i jednocześnie, jej zdaniem równie rozpowszechnione, poczucie nieszczęścia oznacza, że „żyjemy w społeczeństwie pracy, któremu do utrzymania w stanie zadowolenia brakuje wystarczającej ilości pracy"5. Aby być zadowolonym, potrzebna jest człowiekowi praca i związane z nią wynagrodzenie. Można zapytać, o jaki rodzaj pracy tutaj chodzi? Hannah Arend odróżnia pracę od wytwarzania. Praca to wykonywanie czynności, których efekty są nietrwałe, ale niezbędne do życia i funkcjonowania człowieka. To wszelkiego rodzaju działania, które nie pozostawiają po sobie trwałych wytworów, jak przygotowywanie jedzenia, sprzątanie - wszystkie czynności, które na drugi dzień można zaczynać od nowa i które wydają się nie mieć końca. Człowieka, który pracuje w taki lub podobny sposób, Hannah Arendt nazywa animal laborens - zwierzę robocze ${ }^{6}$. Nie jest to człowiek twórca, ponieważ nic z tego, co robi, nie jest trwałe. Pracuje (w sensie wytwarzania) homo faber - człowiek twórca, którego działania pozostawiają trwałe ślady w świecie. Homo faber jest kreatywny w swoim działaniu, wymyśla nowe rzeczy i nowe rozwiązania ${ }^{7}$. Już przez ten fakt można zakładać, że jest to człowiek, którego cieszy własna praca. Jest otoczony szacunkiem i poważaniem ze względu na znaczenie jego wytworów.

Animal laborens pracuje, nie tworzy i nie kreuje nowych przedmiotów. Nie jest kreatywny i nie jest twórcą. Jest przypisany do prac, które należy wykonywać dzień po dniu. Te prace dla wszystkich są bardzo ważne, wręcz konieczne. Mają znaczenie praktyczne, codzienne. To powoduje, że animal laborens jest przekonany, że ma prawo do szczęścia - jego praca jest przecież niezbędna - i że ludzie mogą być „zawsze szczęśliwi”. Praktyczny zmysł podpowiada, że praca charakterystyczna dla zwierzęcia roboczego będzie zawsze potrzebna. Do szczęścia animal laborens wystarcza, że ma pracę. Animal laborens w swojej pracy nie musi myśleć twórczo, co go też mocno odróżnia

${ }^{5}$ H. Arendt, Kondycja ludzka, tłum. A. Łagodzka, Warszawa 20oo, s. 147.

${ }^{6}$ H. Arendt, Kondycja ludzka, dz. cyt., s. 130, 160.

7 H. Arendt, Kondycja ludzka, dz. cyt., s. 130, 160. 
od homo faber - człowieka, który tworzy i dla którego myślenie jest podstawą wykonywanych czynności ${ }^{8}$.

W klasycznych personalistycznych odpowiedziach na pytanie o dobrą pracę pojawiają się stwierdzenia, że ma ona zapewniać środki finansowe umożliwiające życie oraz ma umożliwiać rozwój człowieka9 . Dla Józefa Tischnera dobra praca to praca „dla” - dla siebie i dla innych ludzi, to praca, która jest współpracą i rozmową z drugim człowiekiem i całym światem ${ }^{10}$. Podczas pracy, która jest rozmową, człowiek może się rozwijać i czuć twórcą, nawet gdy dzieła jego rąk są nietrwałe. Taka praca daje człowiekowi poczucie szczęścia.

W rzeczywistości świata konsumpcji praca stała się wyjątkowego rodzaju dobrem, o które się zabiega. Praca w świecie konsumpcji ma na celu przede wszystkim dostarczenie człowiekowi środków finansowych, które umożliwiają osiąganie coraz wyższego statusu społecznego. Działania niepozwalające żądać zapłaty lub wykonywane bez zapłaty nie są rozumiane jako praca, a osoby podejmujące się takich działań, jeśli nie mają dobrego zaplecza finansowego, nie są cenione ${ }^{11}$. Gdzieś wydaje się zanikać wymiar pracy jako współpracy i rozmowy, tak ważnych między innymi dla Tischnera.

Praca zarobkowa w świecie konsumpcji nabiera wyjątkowego znaczenia, ponieważ dzięki pozyskanym środkom finansowym konsument bierze udział w życiu społeczeństwa konsumpcyjnego. Im lepsza płaca za pracę, tym bardziej jest możliwy pełniejszy udział konsumenta w świecie konsumpcji, w którym, jak pisze Michael Sandel, wszystko ma swoją

8 Zob. R. Sennett, Etyka dobrej roboty, tłum. J. Dzierzgowski, Warszawa 2010, S. $11-20$.

9 Odnośnie do personalistycznego podejścia do pracy zob.: J. W. Gałkowski, Człowiek, praca, wartości, Lublin 2012.

${ }^{10}$ J. Tischner, Świat ludzkiej nadziei, Kraków 1994, s. 74, por: J. Tischner, Etyka solidarności oraz Homo sovieticus, wyd. II rozszerzone, Kraków 2005, s. 11-138, również: E. Sperfeld, Arbeit als Gespräch: Józef Tischners Ethik der Solidarnosc, Freiburg 2012.

11 Zob. R. Sennett, Szacunek w świecie nierówności, tłum. J. Dzierzgowski, Warszawa 2012, s. 27n. Sennett opisuje, jak postrzegani są ludzie, którzy wybierają tzw. zawody pomocowe. 
cenę $^{12}$, i im wyższa płaca, tym większą wartość zyskuje pracownik. Gdy wszystko można kupić, rośnie rola i znaczenie pieniądza, co nie pozostaje bez wpływu na człowieka i jego wybory - również te dotyczące pracy - oraz na rozumienie, czym jest szczęście.

Aby praca dawała poczucie szczęścia i radości, człowiek powinien w jakimś stopniu rozumieć, co robi. W świecie konsumpcji niestety, jak pisze Richard Sennett, „Mędrcy nie rozumieją w pełni swojej pracy. Zwykli ludzie też nie"13. Zrozumienie własnej pracy jest problemem i wyzwaniem dla konsumenta. Jest to warunek, aby praca mogła człowieka cieszyć. Józef Tischner powtarzał, że nie ma dobrej pracy bez jakiegoś rozumienia pracy ${ }^{14}$. Sennett twierdzi, że konsument nie rozumie swojej pracy, ponieważ nikt od niego tego nie tylko nie wymaga, ale nawet nie oczekuje ${ }^{15}$. Pracujący konsument jest w większości przedstawicielem gatunku animal laborens i nie pyta o sens swojej pracy, bo nie dostrzega potrzeby takiego pytania. Jest skupiony na zadaniu do wykonania, a nie problemach typu „dlaczego” i „po co”. Za takie pytania korporacje, które są bardzo popularnymi pracodawcami, nie płacą, nie oczekują ich, a nawet w przypadku zwykłych pracowników sobie tego wyraźnie nie życzą ${ }^{16}$.

Zrozumienie własnej pracy to dla konsumenta zarówno wyzwanie, jak i warunek, aby wykonywana praca dawała mu poczucie szczęścia. Sennett mocno podkreśla, że aby praca miała dla człowieka sens, człowiek musi ją w jakimś stopniu rozumieć. Jest to niezmiernie istotne, ponieważ człowiek poznaje się poprzez pracę i poprzez przedmioty, które wytwarza ${ }^{17}$. Brak zrozumienia pracy będzie utrudniał czerpanie z niej radości. Ale konsument skupia się na dobrach materialnych - na

12 Zob. M. Sandel, Czego nie można kupić za pieniądze: moralne granice rynku, tłum. A. Chromik, T. Sikora, , Warszawa 2013, s. 15-28.

${ }^{13}$ R. Sennett, Etyka dobrej roboty, dz. cyt., s. 11.

${ }^{14}$ J. Tischner, Idąc przez puste Błonia, Kraków 2005, s. 65-66.

${ }^{15}$ R. Sennett, Etyka dobrej roboty, dz. cyt., s. 22.

${ }^{16} \mathrm{O}$ charakterze pracy w korporacjach zob. J. Mysona Byrska, Etyka w świecie korporacji, [w:] Prespektivy profesijnej etiky, ed. V. Gluchman, Prešov 2014, s. 301-310.

${ }^{17}$ R. Sennett, Etyka dobrej roboty, dz. cyt., s. 22. 
płacy, która ze zrozumieniem pracy nie musi mieć nic wspólnego. Czy mamy tu do czynienia z nową formą alienacji konsumenta od pracy? Wydaje się, że tak, ale konsument skupiony na materialnych dobrach czerpanych z pracy nawet nie wydaje się być tego świadomy. Rozumienie pracy nie jest mu potrzebne do szczęścia. Dzięki dobrej płacy, mimo braku zrozumienia pracy i jej nietwórczego charakteru, konsument jest szczęśliwy. Jest to szczęście ograniczone do satysfakcji z zarobionych pieniędzy.

Dla konsumenta najważniejsza jest wysokość płacy, ponieważ im płaca wyższa, tym jest więcej wart w świecie konsumpcji. Jednak wynagrodzenie za pracę, takie, które daje rzeczywiste poczucie szczęścia, nie ogranicza się mimo wszystko do wysokości otrzymywanej zapłaty. Również w świecie konsumpcji ważne będą dwie nagrody za pracę: poczucie dumy i zakorzenienie w świecie, które według Sennetta decydują o radości z pracy ${ }^{18}$. Nie można tych dwóch nagród otrzymać, jeśli się zupełnie nie rozumie własnej pracy. Dla nauczonego bezrefleksyjności konsumenta rozumienie tych „nagród” będzie się sprowadzało do wysokości płacy za miesiąc pracy. Nierozumiejący sensu i znaczenia swojej pracy konsument jest dumny z wysokości płacy i zakorzenia się w świecie poprzez nabywanie nowych dóbr. Czuje, że jest u siebie dzięki temu, co posiada, i wydaje się być dzięki powiększanemu stale stanowi posiadania szczęśliwy.

Wszystko, co powyżej opisane, jest związane z promowanym przez świat konsumpcji charakterystycznym światopoglądem, czy inaczej rzecz ujmując, z zespołem wartości, które są preferowane ${ }^{19}$. Przede wszystkim w świecie konsumpcji więcej znaczy lepiej, nowe jest lepsze od starego, a zabawa i posiadanie czasu wolnego są wyznacznikami po-

${ }^{18}$ Zob. R. Sennett, Etyka dobrej roboty, dz. cyt., s. 22, por. J. Tischner, Idąc przez puste Błonia, dz. cyt., s. 66.

${ }_{19}$ Wartości w świecie konsumpcji rozumiane są materialistycznie i utylitarystycznie. Zob. L. Hostyński, Wartości w świecie konsumpcji, Lublin 20o6, s. 5-20. 
zycji i wartości jednostki ${ }^{20}$. W świecie konsumpcji dominują wartości utylitarne, materialne, a wartości duchowe wydają się również podlegać zjawisku „konsumowania”, które według Benjamina Barbera dotyczy wszystkich sfer ludzkiego życia ${ }^{21}$ - stają się towarem do kupienia przez zamożnego konsumenta.

Ponieważ w świecie konsumpcji wszystko ma swoją ceną i wszystko wydaje się kupowalne, konsument stara się zarobić jak najwięcej, aby osiągnąć szczęście na miarę świata konsumpcji, czyli materialny dostatek, i stale podnosić swój społeczny status. Już Herbert Marcuse wiele lat przed rozpowszechnieniem się zjawiska konsumeryzmu stwierdzał, że konsument pracuje ponad konieczność. Nie po to, aby zaspokoić swoje prawdziwe potrzeby, lecz by sprostać wymaganiom społeczeństwa, które naciska, namawia i zmusza do stałego powiększania konsumpcji $^{22}$, zgodnie z zasadą, że więcej znaczy lepiej, że im jednostka więcej konsumuje, tym większa jest jej wartość, i tym bardziej powinna być szczęśliwa, ale równocześnie musi więcej pracować, aby umożliwić sobie większą konsumpcję.

W ten sposób konsument wpada w swego rodzaju „pułapkę szczęścia”23. Pracuje, aby zapewnić sobie dostatnie życie i dzięki temu być szczęśliwym. Praca dobrze płatna powinna dawać mu poczucie szczęścia i cieszyć osiąganymi wynikami. Aby jednak sprostać stale rosnącym wymogom konsumpcyjnym, trzeba pracować coraz więcej i więcej. W miejsce zadowolenia wkracza napięcie i konieczność stałego zwiększania wysiłków, by nie zostać w tyle. Okazuje się, że pragnienie szczęścia zmusza do coraz dłuższej i efektywniejszej pracy. Nasuwa się analo-

${ }^{20}$ Odnośnie do znaczenia zabawy w świecie konsumpcji zob. J. E. Combs, Świat zabawy: narodziny nowego wieku ludycznego, tłum. O. Kaczmarek, Warszawa 2011.

${ }^{21}$ Por. B. Barber, Skonsumowani. Jak rynek psuje dzieci, infantylizuje dorostych i potyka obywateli, tłum. H. Jankowska, Warszawa 2008.

${ }^{22} \mathrm{H}$. Marcuse, Człowiek jednowymiarowy: badania nad ideologia rozwiniętego spoteczeństwa przemystowego, tłum. S. Konopacki, Warszawa 1991, s. 25.

${ }^{23}$ Sformułowanie "pułapka szczęścia” jest zaczerpnięte od Barbary Żmudy, Pułapka szczęścia wspótczesnego człowieka, [w:] Szczęście i radość w sferze społecznej", red. J. Mysona Byrska (tekst w druku). 
gia z jedną ze scen z książki Alicja po drugiej stronie lustra. Alicja biegnie z Królową, w końcu zdyszana staje i pyta o sens tego biegu. Królowa odpowiada, że trzeba biec, aby nie zostać w tyle. Na drugie pytanie Alicji, co trzeba zrobić, aby posuwać się do przodu, pada stwierdzenie, że należy biec dwa razy szybciej. Zdyszana i zmęczona Alicja nie rozumie, o co chodzi, ale biegnie z Królową ${ }^{24}$. Sennett uważa, że konsument jest trawiony namiętnością, którą staje się pogoń za dobrami materialnymi i pragnienie coraz większego szczęścia ${ }^{25}$. Jest to namiętność niszcząca, męcząca i trudna do opanowania, ponieważ świat konsumpcji nie pozwala na działania w kierunku ograniczenia konsumpcji.

Praca w społeczeństwie konsumpcyjnym zmienia swój charakter i znaczenie. Staje się, podobnie jak wszystko inne, jeszcze jednym towarem, jest „utowarowana”, jak pisze Zygmunt Bauman ${ }^{26}$. Również pracownik został zdaniem Baumana „utowarowany”, czyli stał się rodzajem towaru ${ }^{27}$. Utowarowanie pracy i pracownika widać dobrze w charakterystyce poszukiwanych kandydatów. Najlepszym potencjalnym pracownikiem nie jest ten, który ma wyjątkowe kwalifikacje, ale taki, który jest człowiekiem o „zerowym oporze”28. Jest to człowiek bez żadnych zobowiązań, nie posiada: rodziny, kredytu, jakichkolwiek powiązań i obowiązków, a nawet zajmującego hobby. Jest całkowicie dyspozycyjny, a na dodatek żywi lęk przed trwałymi zobowiązaniami - i zgodnie z tym -jest niechętny podpisaniu stałej umowy o pracę, ponieważ może go ona ograniczyć. Pracownik o „zerowym oporze” wydaje się w świecie konsumpcji nastawionym na materialny zysk najbardziej poszukiwanym pracownikiem; gdy wykona zadanie, odejdzie, nie obciążając

${ }^{24}$ Por. L. Carroll, Alicja w krainie czarów. Po drugiej stronie lustra, tłum. B. Kaniewska, Poznań 2010.

${ }^{25}$ R. Sennett, Kultura nowego kapitalizmu, tłum. G. Brzozowski, K. Osłowski, Warszawa 2010, s. 110-111.

${ }^{26}$ Z. Bauman, Konsumowanie życia, tłum. M. Wyrwas-Wiśniewska, Kraków 20o9, S. 16.

27 Z. Bauman, Konsumowanie życia, dz. cyt., s. 66.

${ }^{28}$ Z. Bauman, Konsumowanie życia, dz. cyt.,, s. 15. 
firmy swoją niepotrzebną już osobą. Odejdzie na dodatek w pełni zadowolony i szczęśliwy na miarę świata konsumpcji.

W świecie konsumpcji dobrze płatna praca daje szczęście jedynie początkującym konsumentom, którzy jeszcze nie osiągnęli odpowiedniego statusu konsumpcyjnego i czasami nazywani bywaja "słoikami”"29. Marzeniem każdego konsumenta jest praca, która jest, po pierwsze, przyjemna, po drugie ciekawa, po trzecie dobrze płatna, a po czwarte zostawia dużo wolnego czasu i można ją wykonywać w dowolnym miejscu, np. we własnym przytulnym pokoju lub w uroczej kawiarni. To praca pozwalająca na samorealizację, rozwój, podnoszenie kwalifikacji. Jest ciekawa i wiąże się z podróżami, poznawaniem innych ludzi i krajów. Z definicji daje konsumentowi szczęście i radość. Ciekawość jest przecież jedną z ważnych wartości świata konsumpcji ${ }^{30}$.

Wymarzona praca budzi zazdrość wszystkich, którzy jej nie wykonują i zmuszeni są do nużącego wielogodzinnego przesiadywania w biurach i kancelariach, w stroju wymaganym przez dress code firmy. Praca - marzenie konsumenta wydaje się pracą charakterystyczną dla Arendtowskiego homo faber - człowieka twórcy, myślącego, kreatywnego i już przez to szczęśliwego i zadowolonego. Szczęśliwy pracownik świata konsumpcji w pracy się nie męczy i praca go w żaden sposób nie ogranicza $^{31}$. Co więcej, jest to praca wykonywana z pasją i wręcz utożsamiona $z$ hobby. Jej wykonywanie nie męczy, ponieważ jest to ten szereg czynności, który człowiek z największą przyjemnością wykonuje w czasie wolnym. Tak pracujący człowiek nie odróżnia czasu przeznaczonego na pracę od czasu odpoczynku. Wykonywana praca bawi go

${ }^{29}$ "Słoik” to osoba, która pracuje w wielkim mieście, na weekendy jeździ do rodziny na wieś i przywozi w przysłowiowych słoikach jedzenie na cały tydzień - nie ma ani czasu, ani ochoty gotować, a dzięki domowemu jedzeniu oszczędza na wydatkach.

${ }^{30}$ Odnośnie do ciekawości zob. J. Baudrillard, Społeczeństwo konsumpcyjne ..., dz. cyt., s. 21.

${ }^{31}$ Zob. D. Grabowski, Miejsce pracy w kulturze konsumpcji. Etos pasjonujacej i interesujacej pracy jako forma jej konsumpcji, [w:] W supermarkecie szczęścia. O różnorodności zachowań konsumenckich w kontekście jakości życia”, red. M. Górnik-Durose, A. M. Zawadzka, Warszawa 2012, s. 56-77. 
w najwyższym stopniu. Wolny od rutyny i stroju wymaganego przez zatrudniające firmy, szczęśliwy wybraniec świata konsumpcji pracuje nad filiżanką pachnącej kawy, w pięknym miejscu, i w godzinach przez siebie wybranych. Całkowita idylla i marzenie szeregowego konsumenta.

Taka praca pozostaje niestety dla większości pracowników jedynie nieosiągalnym marzeniem, i to na dodatek mocno frustrującym. Szeregowy konsument pracuje zwykle w korporacji, potocznie nazywany jest korpoludkiem. W drodze do pracy często może spotykać szczęśliwych i wolnych ludzi pracujących i przesiadujących w kawiarniach. Jego praca jest nieciekawa, rutynowa, jest przywiązany do miejsca, ograniczony godzinami otwarcia biura lub zakładu pracy. Przeciętny konsument zazdrości wybrańcowi i marzy o lepszej pracy, sukcesie i szczęściu, jakie daje taka wymarzona praca. Jeśli oczywiście jest jeszcze w stanie marzyć.

Kolejny problem pracy w społeczeństwie konsumpcyjnym to zanikająca korelacja ciężka praca - dobre wynagrodzenie. Zjawisko prekaryzacji pokazuje, że ciężka praca nie musi koniecznie dawać dobrego wynagrodzenia $^{32}$. Duże pieniądze daje taki rodzaj pracy, który jest pożądany w świecie konsumpcji; dzieci na pytanie, kim chcesz być, odpowiadają: chcę być sławny/a; - a co będziesz robić? - wszystko jedno.

Jaka praca zatem w społeczeństwie konsumpcyjnym daje szczęście i radość zgodnie z wytycznymi świata konsumpcji? Dla początkującego konsumenta jest to przede wszystkim praca, która daje duże pieniądze. Dla konsumenta już trochę bardziej zawansowanego będzie to praca, która zostawia wolny czas na konsumpcję - uprawianie egzotycznego hobby itp.. Wymarzona praca to praca, która nie przywiązuje do miejsca, ciekawa i przyjemna, w której człowiek może realizować swoje zainteresowania. Etos pracy ciekawej wygrywa współcześnie z cechami pracy, które były istotne jeszcze w społeczeństwie produkcyjnym: praca na rzecz innych, oszczędzanie itp. Znaczenie traci to, co się robi w pracy - ważne, by były to zajęcia ciekawe, ich etyczny wymiar często zupełnie nie jest brany pod uwagę.

${ }^{32}$ Odnośnie do zjawiska prekaryzacji zob.: J. Urbański, Prekariat i nowa walka klas: przeobrażenia współczesnej klasy pracowniczej i jej form walki, Warszawa 2014. 
Tak pracujący człowiek ma być szczęśliwy. Pytanie jednak, czy rzeczywiście jest? Na pewno żyje mu się lepiej niż opisywanym przez Zygmunta Baumana „ludziom - odpadom”, ludziom, którzy są zbędni, a „zbędność zakłada trwałość i naturalność takiego stanu. [...] Być zbędnym znaczy być nadliczbowym, niepotrzebnym, bezużytecznym, [...] przeznaczonym do wyrzucenia"33. Tych ludzi konsument wydaje się zupełnie nie dostrzegać, ponieważ gdyby ich dostrzegł, świadomość ich istnienia nie pozwoliłaby na spokojną konsumpcję.

W pracy, w której estetyka jest ważniejsza niż etyka, brakuje odniesień, o których jeszcze nie tak dawno pisano: odniesienia do drugiego, działania dla innych. Wydaje się, że zanika wymiar współpracy. Nie współpraca, nie tworzenie czegoś dla innych, ale charakterystyczne dla konsumpcjonizmu skupienie na sobie i własnych potrzebach staje się głównym celem pracy.

Czy człowiek, który skupia się tylko na sobie, może być naprawdę szczęśliwy? Paradoksalnie, może właśnie z powodu niedostrzegania innych i ich potrzeb nie wie, że istnieją ludzie potrzebujący pomocy, i to pozwala mu na bycie szczęśliwym. Jest dla siebie, i tylko dla siebie - tak długo trwa w dobrym samopoczuciu, jak długo ma pieniądze i nie potrzebuje od innych ludzi takiej pomocy, której nie jest w stanie sobie kupić.

\section{WORK AS A SOURCE OF JOY AND HAPPINESS IN CONSUMERIST SOCIETY}

SUMMARY

Work can be a source of human happiness and joy. However, to make this possible, it should fulfil several criteria. In the world of consumption, the most important criteria of a good work is a high salary. The Happiness, which the

${ }^{33}$ Z. Bauman, Życie na przemiat, dz. cyt., s. 25. 
work can give to a human being, is measured by the content of one's wallet. A dream work for a consumer is a work which is interesting, well-paid, not connected to one place, and giving a lot of free time and freedom. The article shows that such a work is not available for all, and a dream about it makes a regular/average working man unhappy.

KEYWORDS

work, happiness and joy, consumption 